Revta brasil. Bot., São Paulo, V.24, n.4, p.425-433, dez. 2001

\title{
Grãos de pólen anômalos no clone CP76 de Anacardium occidentale L. (Anacardiaceae)
}

\author{
JOÃOMARCELO SANTOS DE OLIVEIRA ${ }^{1,3}$, JORGEERNESTODE \\ ARAUJO MARIATH $^{1}$ e DALVA MARIA BUENO ${ }^{2}$
}

(recebido: 29 de novembro de 2000; aceito: 8 de agosto de 2001)

\begin{abstract}
Anomalous pollen grains in the clone CP76 of Anacardium occidentale L. (Anacardiaceae)). Anomalies of male gametophyte development was observed during anther development investigation in the clone CP76 of Anacardium occidentale. Androspores that stop development before the first pollen mitosis, and grains that show male gametophyte anomalies in early stage of development, was observed. The anomalous first mitosis generate two identical cells, or quite, or grains where cell plate was partially formed. Nuclear fusion occurs in those cells where partial cell walls were formed. The interruption of development before first pollen mitosis occurs in high frequency, on the other hand, the anomalies related with the first pollen mitosis are very rare.
\end{abstract}

RESUMO - (Grãos de pólen anômalos no clone CP76 de Anacardium occidentale L. (Anacardiaceae)). Durante a investigação do desenvolvimento das anteras e grãos de pólen no clone CP76 de Anacardium occidentale foram observadas anomalias relacionadas ao desenvolvimento do gametófito masculino. Foram observados andrósporos que interromperam seu desenvolvimento momentos antes da primeira mitose, além de grãos que apresentaram anomalias relacionadas à fase inicial da gametogênese masculina. A primeira mitose anômala produziu grãos de pólen binucleados com células idênticas, ou quase, e ainda grãos onde a parede celular, oriunda da primeira mitose, foi incompletamente formada. Fusão nuclear foi observada nos grãos onde a parede celular foi incompletamente formada. A interrupção no desenvolvimento é muito freqüente, ao contrário das anomalias relacionadas à primeira mitose, de ocorrência muito rara.

Key words - Anacardiaceae, Anacardium occidentale, male gametogenesis, anomalous pollen grains

\section{Introdução}

A gametogênese masculina, em angiospermas, é caracterizada pela diferenciação das células generativa e vegetativa, as quais derivam da primeira mitose de caráter assimétrico. A célula generativa, através de uma segunda divisão mitótica, dá origem aos gametas masculinos, enquanto que a célula vegetativa coordena a formação e desenvolvimento do tubo polínico através dos tecidos do estigma e do estilete até o ginófito, onde os gametas irão cumprir a função da dupla fecundação. Portanto, o programa gametofítico de desenvolvimento determina que as células generativa e vegetativa cumpram seu papel na alternância de gerações. No clone CP76 de

1. Universidade Federal do Rio Grande do Sul, Departamento de Botânica, Laboratório de Anatomia Vegetal, Av. Bento Gonçalves, 9500, Prédio 43423, 91501-970 Porto Alegre, RS, Brasil.

2. Empresa Brasileira de Pesquisa Agropecuária EMBRAPA/CNPAT, Agroindústria Tropical, Rua Dra. Sara Mesquita, 2270 Pici, 60511-110 Fortaleza, CE, Brasil.

3. Autor para correspondência: linneau@bol.com.br
Anacardium occidentale L. (cajueiro-anão precoce) o processo de gametogênese masculina é semelhante ao observado para outras angiospermas (Knox 1984). Porém, no referido clone são observados andrósporos e grãos de pólen jovens que sofreram alteração no programa gametofítico de desenvolvimento, apresentando-se funcionalmente estéreis. Essas alterações assemelham-se aos primeiros passos morfogênicos da embriogênese observados in vivo e in vitro em outras espécies como Datura innoxia (Collins et al. 1974), Hordeum vulgare (Dale 1975), Nicotiana tabacum (Heberle-Bors \& Reinert 1979), Triticum aestivum (Reynolds 1993) e Glycine max (Kaltchuk-Santos et al. 1993). Nessas espécies a alteração na rota gametofítica do desenvolvimento dos andrósporos e grãos de pólen jovens está intimamente relacionada com a capacidade embriogênica e conseqüente produção de plantas haplóides, a partir destes grãos. As plantas então originadas, completamente homozigotas, são muito importantes em estudos sobre genética e melhoramento vegetal (Maheshwari et al. 1982, Touraev et al. 1997), portanto, essenciais para programas de desenvolvimento agrícola. Segundo Grando \& Moraes-Fernandes (1997) fatores 
genéticos, fisiológicos e ambientais estão envolvidos na alteração do programa gametofítico de desenvolvimento. Heberle-Bors (1982) cita que o balanço sexual está intimamente relacionado ao aumento da frequência de grãos de pólen anormais, denominados de pólen $\mathrm{P}$, os quais possuem competência embriogênica. Em Brassica napus (Ilic'Grubor et al. 1998) o choque térmico é responsável pela determinação do desenvolvimento esporofítico apresentado pelos andrósporos dessa espécie. $\mathrm{O}$ clone CP76 de A. occidentale apresenta, in vivo, alterações no programa gametofítico de desenvolvimento à semelhança do que foi observado em outras espécies de interesse econômico, citadas acima, onde plantas haplóides foram obtidas.

O objetivo deste trabalho é apresentar a morfologia das alterações do desenvolvimento gametofítico, observadas in vivo no clone CP76, e propor a existência de potencialidade embriogênica nos andrósporos do referido clone.

\section{Material e métodos}

Material botânico - O cajueiro-anão precoce foi resultado de seleção fenotípica individual na estação experimental de Pacajus - CE, controlando-se a produção, anualmente, a partir de 1965. Os resultados dessa seleção foram quatro clones comerciais denominados de CCP06, СCP09, CCP76 e CCP 1001. Desses, o clone CP76 é o mais difundido por possuir melhores características de pedicelo hipertrofiado maduro para consumo in natura, além das características do fruto para indústria.

Flores, de dimensões de $2,9 \mathrm{~mm}$ a $8,8 \mathrm{~mm}$ de comprimento (Oliveira 1998), em fase de gametogênese masculina, foram coletadas na Estação Experimental da EMBRAPA em Pacajus - CE, Brasil. O material foi fixado em glutaraldeído $1 \%$ e formaldeído 4\% (McDowell \& Trump 1976) por 24 horas à temperatura ambiente, desidratado em série etílica e incluído em hidroxietilmetacrilato (Gerrits \& Smid 1983). Secções foram realizadas em micrótomo Leitz, modelo 1400, na espessura de $2 \mathrm{~mm}$, coradas com azul de toluidina, e também submetidas ao ácido periódico - reativo de Schiff (O’Brien \& McCully 1981). Fotomicrografias foram realizadas em microscópio óptico Leitz, Dialux 20EB com câmara fotográfica Leica MD2.

\section{Resultados e Discussão}

O clone CP76 de Anacardium occidentale apresenta flores completas e estaminadas, as quais ocorrem em panículas terminais. As flores são pentâmeras e diplostêmones, sendo que um dos estames, abaxial ao carpelo, é muito mais desenvolvido que os demais. O padrão para diferenciação de ambos os tipos de estames é idêntico nas flores citadas. Apenas um número maior de células, no meristema floral, torna-se comprometido para a formação do estame maior e, assim um maior número de grãos de pólen (andrófitos) são formados nas anteras maiores (Oliveira \& Mariath 2001). Um carpelo unilocular, com um único rudimento seminal, ocorre nas flores completas, porém ambos interrompem seu desenvolvimento para originar as flores estaminadas. Em indivíduos selvagens a flor terminal dos ramos é completa. Entretanto, no clone CP76 a flor terminal, em geral, é estaminada (J.M.S. Oliveira, J.E.A. Mariath \& D.M. Bueno, dado não publicado).

A gametogênese masculina inicia após vacuolação total do andrósporo maduro (figura 1) para que ocorra a primeira mitose assimétrica, resultando as células generativa e vegetativa. A célula generativa, inicialmente lenticular, tem sua parede interna composta por pectinas e principalmente calose, a qual é contínua com a intina (figura 2). A célula vegetativa herda quase todo o citoplasma do andrósporo genitor, no qual o único processo de amilogênese irá ocorrer logo após a conclusão da primeira mitose (figuras 2, 3, 5). Posteriormente, a célula generativa migra em direção ao núcleo da célula vegetativa (figura 3 ), onde formam a unidade germinativa masculina, após associação estrutural (figura 4). A parede do pólen é composta de exina e intina. A exina é subdividida em ectexina e endexina, à semelhança do que foi descrito para outras espécies da família Anacardiaceae (Erdtman 1943). A intina, por sua vez, apresenta uma porção externa, a exintina, onde predominam pectinas, e uma porção interna, a endintina, de composição celulósica (figuras 2,3 ), à semelhança do que foi descrito para Canna e Heliconia (Kress \& Stone 1982). Algumas dessas características podem ser consideradas como padrão para as angiospermas (Maheshwari 1950, Knox 1984) e foram descritas para espécies como Nicotiana tabacum (Yu \& Russel 1994) e Plumbago zeylanica (Russel et al. 1996). Assim, após a primeira mitose assimétrica é garantida a formação da célula vegetativa (ou célula sifonogênica) e da célula generativa (ou célula gametogênica), as quais são fundamentais para o processo de formação do tubo polínico e de dupla fecundação em angiospermas (Tanaka 1997, Ueda et al. 2000). Porém, entre os grãos de pólen com desenvolvimento normal foram observados grãos de pólen anômalos, onde a célula 

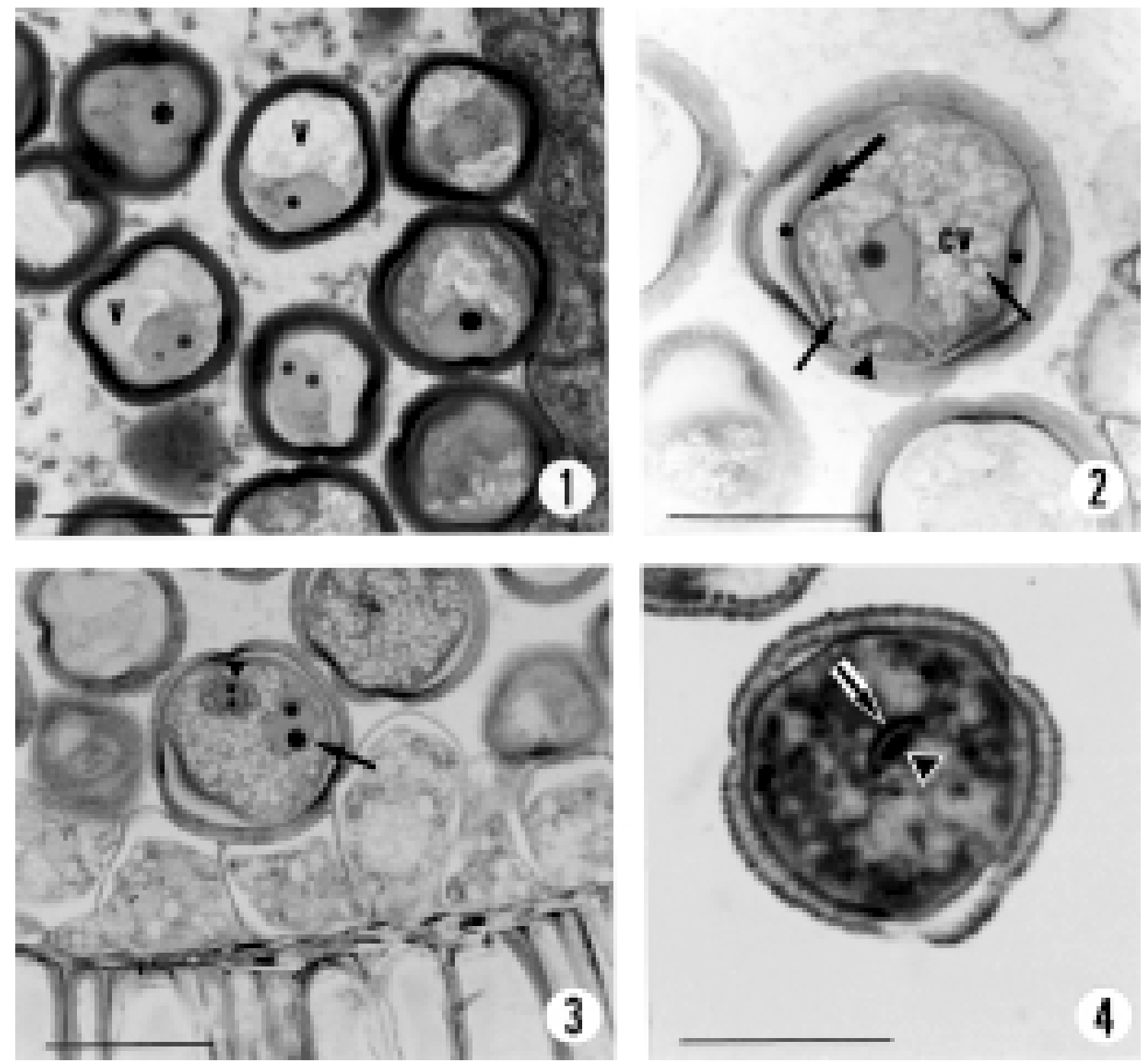

Figuras 1-4. Principais eventos da gametogênese masculina em anteras do clone CP76 de Anacardium occidentale. 1. Grande vacúolo (v) desloca o núcleo haplóide para o pólo generativo, junto a esporoderme, local onde ocorrerá a primeira mitose de caráter assimétrico. 2. A primeira mitose assimétrica origina as células generativa (cabeça de seta) e a célula vegetativa (cv); grãos de amido (setas pequenas), grande desenvolvimento da exintina $(*)$, deposito da endintina. (seta grande). 3. Célula generativa (cabeça de seta) em processo de migração em direção ao núcleo da célula vegetativa (seta). 4. Unidade germinativa formada num grão de pólen em uma antera deiscente, célula generativa (cabeça de seta) e núcleo da célula vegetativa (seta). Escala na figura $1=20 \mu \mathrm{m}$, nas figuras $2,3,4=35 \mu \mathrm{m}$.

generativa não é formada ou é formada muito tardiamente, sendo portanto, considerados funcionalmente estéreis.

A interrupção do desenvolvimento dos andrósporos, imediatamente antes da primeira mitose (figura 5), é uma anomalia freqüentemente observada em ambos os tipos de anteras e em ambos os tipos de flores do clone CP76 de A. occidentale. Tal anomalia, normalmente atinge até, aproximadamente, metade dos andrósporos nas anteras afetadas. Os andrósporos nesses casos degeneram durante as fases intermediária ou final da gametogênese, ou acabam sofrendo a primeira mitose durante a deiscência da antera (figuras 6,7). Nenhuma alteração na esporoderme desses grãos foi observada. Dale (1975) observou em Hordeum vulgare cv. Akka a 
ocorrência de grãos dimórficos entre anteras, os quais também apresentaram atraso no desenvolvimento. $\mathrm{O}$ mesmo autor verificou que os grãos dimórficos ocorriam predominantemente na porção basal da antera. Porém, no clone CP76 a distribuição dos grãos anômalos foi uniforme nos esporângios. Dale (1975) salienta, ainda, que existe em $H$. vulgare uma íntima relação entre estes grãos anômalos e a produção de
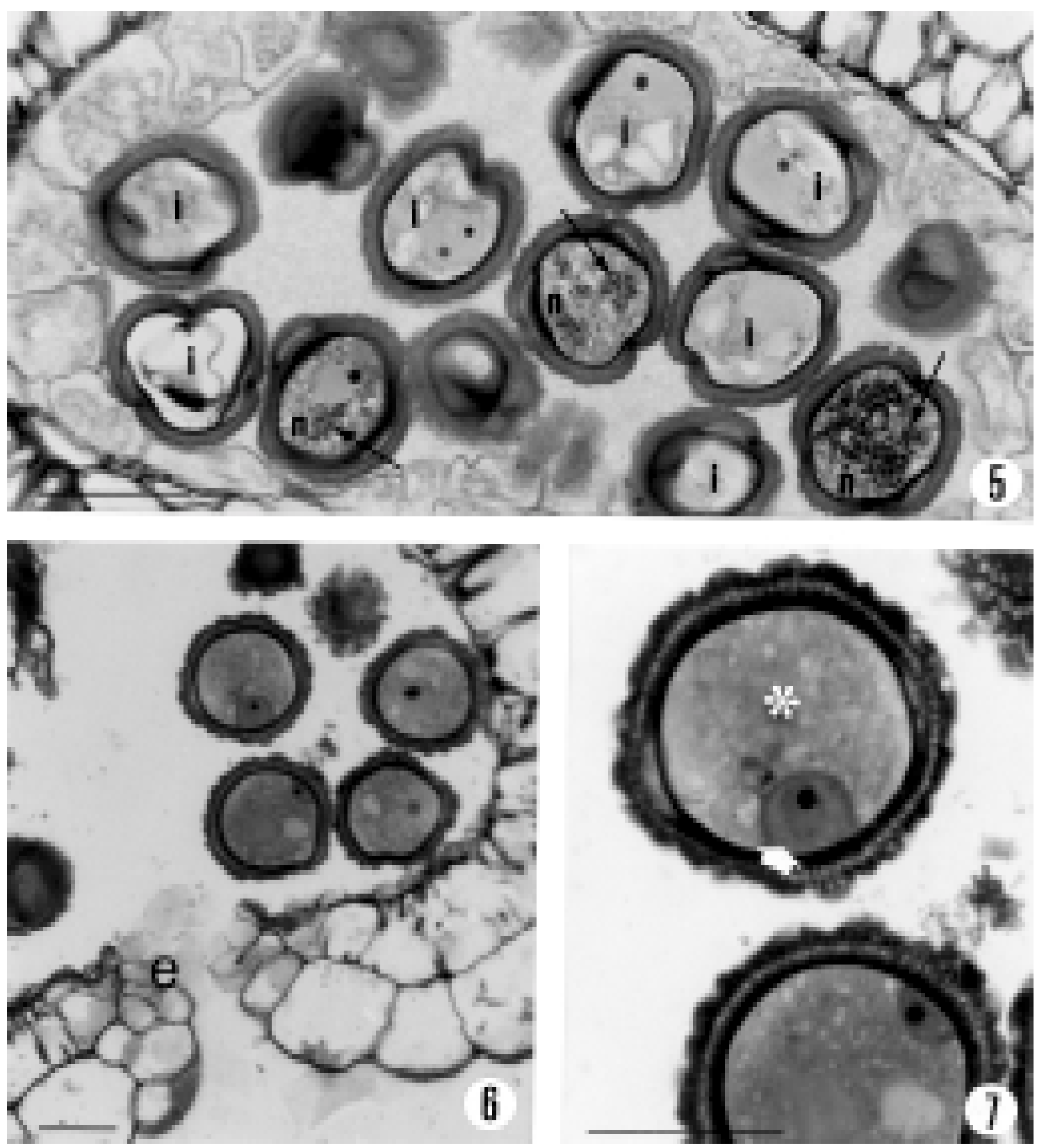

Figuras 5-7. Andrósporos e andrófitos anômalos em anteras do clone CP76 de Anacardium occidentale. 5. Antera menor seccionada longitudinalmente mostrando grãos de pólen que interromperam seu desenvolvimento (i) e grãos de pólen normais (n), grãos de amido (setas) desenvolvendo-se nos grãos de pólen normais. 6. Grãos de pólen com a primeira mitose ocorrendo durante a deiscência da antera $(\mathrm{e}=$ linha de estômio rompida). 7. Detalhe de grãos de pólen apresentado na figura 6 , não apresentando o desenvolvimento de grãos de amido, mostrando célula generativa (seta) e célula vegetativa $(*)$. Escala nas figuras $5,6=35 \mu \mathrm{m}$, na figura $7=17 \mu \mathrm{m}$. 
calos em anteras submetidas à cultura, onde o aumento do percentual de grãos anômalos resultou em um maior número de calos. Kaltchuk-Santos et al. (1993) observaram, em soja, a ocorrência de grãos dimórficos com atraso no desenvolvimento em relação aos grãos de pólen normais. Heberle-Bors \& Reinert (1979), em tabaco, denominaram de pólen P os grãos anômalos que, além do atraso no desenvolvimento, apresentavam fraca reação ao carmim acético e tamanho inferior aos grãos normais. Grãos desse tipo foram, observados também, em outras espécies in vivo e in vitro (Buyser \& Picard 1975, Horner \& Street 1978, Rashid 1983).

Tanaka (1997) cita que a ação de agentes determinantes do desenvolvimento gametofítico inicia após a primeira mitose. Grando \& MoraesFernandes (1997) e Sangwan (1986) citam que o vacúolo, o qual também é observado no cajueiro ao final da esporogênese, tem ação lítica sobre os elementos determinantes do desenvolvimento esporofítico. Em algumas espécies essa fase do desenvolvimento está relacionada a um aumento na freqüência de plantas haplóides, ou de calos obtidos em meio de cultura apropriado (Sunderland \& Wicks 1971, Heberle-Bors \& Reinert 1979, Maheshwari et al. 1980, Ilic'-Grubor et al. 1998). Assim, a interrupção no desenvolvimento dos andrósporos do clone CP76 pode representar uma janela no desenvolvimento para a obtenção de plantas haplóides, onde essa anomalia do desenvolvimento pode corresponder a um momento de indeterminação no destino do núcleo haplóide desses grãos dimórficos. Porém se desconhece a causa para tal anomalia. Sunderland \& Huang (1987) denominaram de "residuais" os andrósporos, no gênero Paeonia, que apresentavam atraso no desenvolvimento, e ainda sugeriram que esse evento deveria ser causado por algum fator externo ao andrósporo.

Em algumas flores foi observado, em ambos os tipos de anteras, que entre os grãos com desenvolvimento normal ocorriam grãos de pólen binucleados (figuras 8, 9, 13), grãos de pólen que haviam sofrido a primeira mitose simétrica ou quase (figuras 11,12) e ainda grãos onde a primeira mitose, também anômala, deu origem a uma parede celular incompleta (figuras 9, 10).

A fusão nuclear foi observada nos andrófitos onde a citocinese produziu uma parede celular incompleta (figuras 8, 9), ou onde a mesma não ocorreu (figuras 13-15). Assim, o núcleo que iria compor a célula generativa migra em direção ao núcleo irmão, em um processo que imita o processo de gametogênese normal (figuras 8, 9). O processo de fusão ocorre após gradual difusão cromatínica e alteração da morfologia, de ambos os núcleos, na região de contato (figuras 13,14$)$. Posteriormente, ocorre a confluência da cariolinfa de ambos núcleos, os quais originam um núcleo maior, posicionado na região central do grão de pólen (figura 15). Os núcleos antes da fusão, bem como aquele núcleo duplo haplóide derivado da fusão, apresentam as mesmas características estruturais do núcleo da célula vegetativa.

Sunderland (1973) identificou a primeira mitose simétrica como sendo a principal rota embriogênica na formação de plantas haplóides, classificando essa divisão e suas variantes como sendo do tipo B, quando núcleos irmãos iguais, tipo vegetativo, são formados; ou do tipo A, quando um dos núcleos, tipo generativo, é formado. Sunderland \& Huang (1987) descrevem que a presença do vacúolo e a alteração do plano do fragmoplasto são responsáveis pela formação de paredes incompletas. Reynolds (1993) observou em Triticum aestivum a ocorrência de andrósporos binucleados in vitro, embora não os tenha observado in vivo. Dunwell (1992) cita que o meio de cultura atuaria como um estímulo externo, o qual permitiria a alteração do programa de desenvolvimento. Sangwan \& Sangwan-Norreel (1987) observaram a fusão de núcleos adjacentes em andrósporos de Datura innoxia. Sunderland et al. (1974) e Collins et al. (1974) descreveram que em $D$. innoxia grãos de pólen do tipo B tornam-se duplohaplóides após fusão nuclear, quando núcleos tipovegetativos, em mitose simultânea, compartilham o mesmo fuso mitótico. Henry (1998) cita que a duplicação cromossômica via fusão é um evento pouco comum, uma vez que a freqüência de sincronia no processo mitótico é baixa. Touraev et al. (1997) citam que a fusão nuclear seria um caminho assumido por grãos embriogênicos em cultura, resultando em duplo-haplóides espontâneos como, também, observado por Sunderland \& Evans (1980) em cevada. Sunderland et al. (1974) comentam que esses eventos de duplicação espontânea, em processos de regeneração de calos, são importantes, pois a duplicação do complemento cromossômico pela colchicina apresenta efeitos deletérios. Em soja, Kaltchuk-Santos et al. (1993) observaram uma baixa freqüência de grãos binucleados atípicos sugerindo, 
ainda, que esses grãos poderiam surgir a partir da primeira mitose simétrica em pólens tipo P. No presente estudo, nos casos onde a primeira mitose dividiu completamente o citoplasma do andrósporo, foi observado que ambas as células derivadas apresentavam as mesmas características de uma célula vegetativa, ou seja, ambas acumularam em seus citoplasmas reservas nutritivas e seus núcleos apresentaram gradual difusão cromatínica e nucléolos grandes. O mesmo foi observado por Tanaka \& Ito (1981) e Tanaka et al. (1998). Bouharmont (1977) e Wilson et al. (1978) demonstraram que em botões florais, sujeitos a tratamento de baixa temperatura, ocorre um aumento no número de andrósporos que se dividem em duas células iguais que posteriormente, originam embriões.

Em ambos os tipos de anomalias descritas acima a esporoderme sofreu alterações em seu padrão, exceto na anomalia descrita como interrupção no desenvolvimento dos andrósporos. Devido ao acúmulo maior de esporopolenina, a ectexina perde seu padrão estriado, e a porção interna da intina, a endintina, não foi detectada sob microscopia óptica. A endintina, no clone CP76 de A. occidentale, é depositada no início da gametogênese e, nos grãos anômalos, a sua ausência pode servir como um
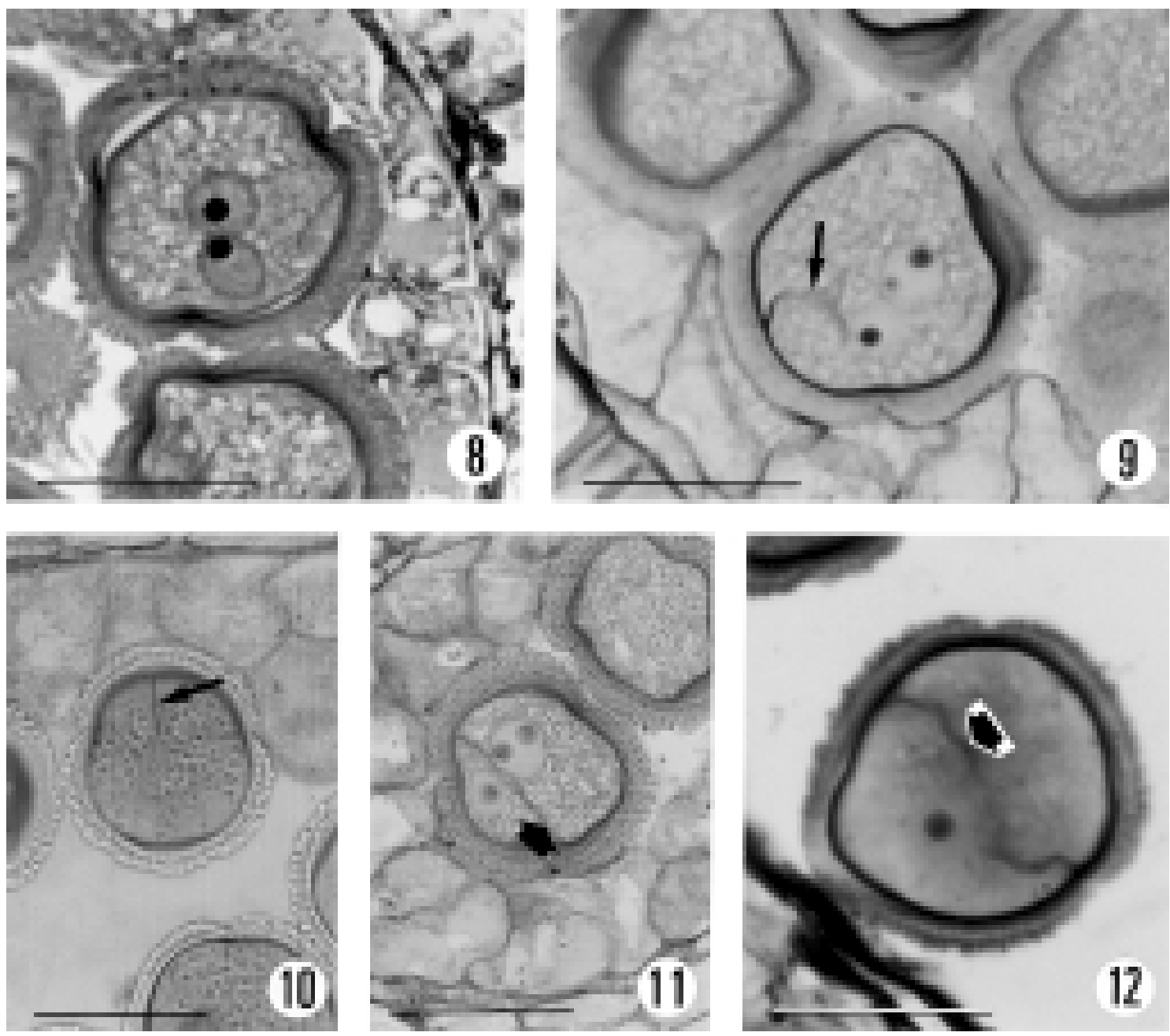

Figuras 8-12. Secções transversais de anteras do clone CP76 de Anacardium occidentale mostram andrófitos anômalos. 8. Grão de pólen binucleado onde os núcleos irmãos são semelhantes e apresentam as mesmas características de núcleo de uma célula vegetativa (ver figura 3). 9-10. Grãos de pólen com paredes celulares incompletas (setas). 11-12. Grãos de pólen bicelulares, as células derivadas da primeira mitose anômala apresentam as mesmas características observadas em uma célula vegetativa. Setas indicam paredes celulares. Escala nas figuras $8,9,11,12=35 \mu \mathrm{m}$, na figura $10=17 \mu \mathrm{m}$. 
marcador morfológico para aquela fase do desenvolvimento onde algum fator pode ter
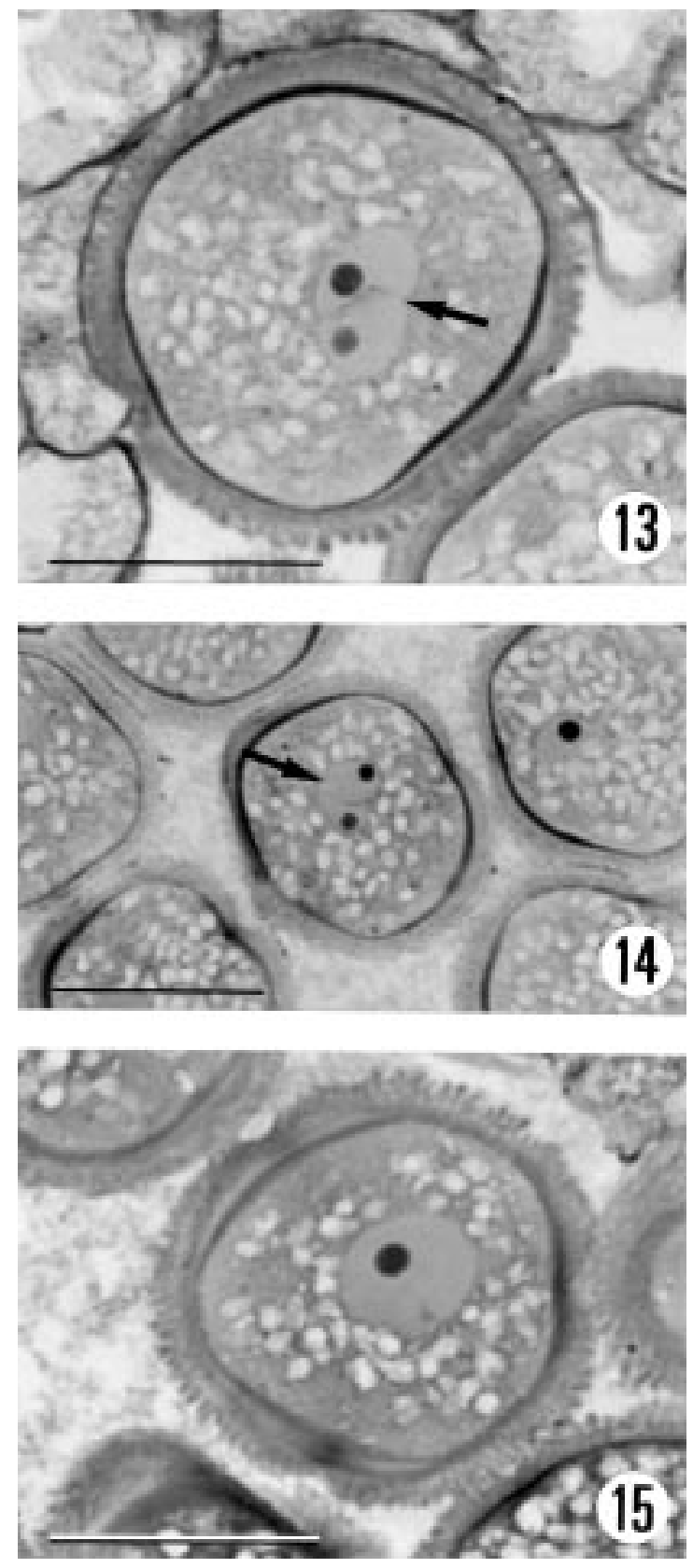

Figuras 13-15. Andrófitos anômalos em anteras do clone CP76 de Anacardium occidentale. 13-14. Fusão dos núcleos irmãos derivados da primeira mitose anômala (seta). 15. No centro do grão de pólen ocorre o núcleo duplo-haplóide oriundo do processo de fusão nuclear representado nas figuras 13,14 . Escala nas figuras $13,15=35 \mu \mathrm{m}$, na figura $14=$ $17 \mu \mathrm{m}$. interrompido o processo de desenvolvimento do andrósporo. Nos grãos anômalos onde houve a formação de parede, independentemente desta ser completa ou não, observou-se sua continuidade direta com a exintina (figuras 9-12). Em alguns esporângios, onde estas anomalias ocorreram, observou-se o acúmulo demasiado de esporopolenina no ápice locular, entretanto, o tapete não apresentou alterações estruturais. Os demais estratos parietais, a epiderme, bem como o tecido conectivo, também não apresentaram alterações em relação ao padrão observado para o referido clone.

Andrófitos binucleados são considerados por Kaltchuk-Santos et al. (1997) e Liu \& Zhao (1986), em soja, como uma rota androgênica importante, bem como andrófitos bicelulares simétricos, ou quase, como citado por Wilson et al. (1978) e Maheshwari et al. (1982).

No presente estudo as anomalias descritas atingiram, aproximadamente, $50-60 \%$ dos andrófitos nas anteras onde ocorreram. Foi freqüente a ocorrência de grãos binucleados, grãos bicelulares, e grãos com paredes celulares incompletas, ao contrário dos grãos uninucleados. Porém, neste trabalho, grãos binucleados e grãos uninucleados são considerados como diferentes momentos do mesmo processo de desenvolvimento, o qual resulta em andrófitos duplo-haplóides.

Cabe salientar, também como uma anomalia, a alteração da distribuição das flores nas panículas do referido clone, no qual geralmente as flores estaminadas ocorrem em posições terminais, em contraposição aos indivíduos selvagens, nos quais as posições terminais são ocupadas por flores completas (Copeland 1962). Em indivíduos selvagens, bem como, no clone CP76 as flores de posições laterais são estaminadas. Devido ao fato das flores estaminadas surgirem por interrupção do desenvolvimento do rudimento seminal após sua ontogenia ter sido ativada, sugerimos que o fator que determina o aumento no número de flores estaminadas, com conseqüente alteração na configuração das panículas, pode estar de algum modo influenciando o surgimento das anomalias descritas no presente trabalho.

Heberle-Bors (1982) descreve que o aumento na freqüência de grãos, capazes de adquirir competência embriogênica, está associado à alteração no balanço sexual, principalmente quando este ocorre em direção à feminilização. Segundo Heberle-Bors (1982) a 
feminilização em N. tabacum foi obtida em plantas crescendo sob condições de dias curtos e baixa temperatura $\left(15\right.$ ou $\left.18^{\circ} \mathrm{C}\right)$. Em plantas crescendo sob condições de dias longos e alta temperatura $\left(27^{\circ} \mathrm{C}\right)$ foi observada a masculinização das plantas, onde o autor cita um leve aumento na freqüência de grãos mortos, os quais poderiam, inicialmente, ser capazes de adquirir competência embriogênica. Rashid (1983) cita que a manutenção da viabilidade de grãos dimórficos é obtida com a redução da temperatura. Entretanto, em B. napus o tratamento dos grãos de pólen com alta temperatura resultava em competência androgênica (Zaki \& Dickinson 1991). Portanto, a feminilização ou a masculinização, oriundas de alterações no fotoperíodo, determinam, aparentemente, o aumento da freqüência de grãos cuja rota de desenvolvimento é indeterminada. O fator temperatura, de acordo com a literatura, pode por sua vez, determinar ou induzir o andrósporo haplóide, ou grão de pólen jovem, a assumir a rota embriogênica de desenvolvimento, tanto pela alteração do padrão de divisão do núcleo haplóide quanto pela degradação ou inativação de agentes gametofíticos.

Em anteras do clone CP76 de $A$. occidentale foram observadas in vivo algumas características apresentadas por várias espécies que, sob regime de cultura, apresentam potencial androgenético. As anomalias apresentadas para os andrófitos abrem uma possibilidade para estudos na obtenção de plantas haplóides no clone CP76, uma vez que, os passos morfogenéticos iniciais, necessários na alteração da rota gametofítica para a rota embriogênica, ocorrem no referido clone.

Agradecimentos - Agradecemos a Dra. Eliane Kaltchuk dos Santos, do Depto de Genética da UFRGS pela revisão crítica e pelas sugestões que muito enriqueceram o presente trabalho.

\section{Referências bibliográficas}

BOUHARMONT, J. 1977. Cytology of microspores and calli after anther culture in Hordeum vulgare. Caryologia 30:351-360.

BUYSER, J. \& PICARD, E. 1975. Observation de divisions supplémentaires dans les grains de pollen de plants homozigotas de blé tendre (Triticum aestivum L.) obtenues par androgénese in vitro. Comptes Rendus Academy des Sciences 281:1153-1156.

COLLINS, G.B., DUNWELL, J.M. \& SUNDERLAND, N. 1974. Irregular microspore formation in Datura innoxia and its relevance to anther culture. Protoplasma 82:365-378.
COPELAND, H.F. 1962. Observations on the reproductive structures of Anacardium occidentale. Phytomorphology 11:315-325.

DALE, P.J. 1975. Pollen dimorphism and anther culture in barley. Planta 127:213-220.

DUNWELL, J.M. 1992. Mechanisms of microspore embryogenesis. In Reproductive biology and plant breeding (Y. Dattee, C. Dumas \& A. Gallais, eds.). Springer-Verlag, New York, p.121-130.

ERDTMAN, G. 1943. An introduction to pollen analysis. Walthman, New York.

GERRITS, P.O. \& SMID, L. 1983. A new, less toxic polymerization system for the embedding of soft tissues in glycol methacrylate and subsequent preparing of serial sections. Journal of Microscopy 132:81-85.

GRANDO, M.F. \& MORAES-FERNANDES, M.I.B. 1997. Two point deterministic model for acquisition of in vitro pollen grain androgenetic capacity based on wheat studies. Brazilian Journal of Genetics 20:467-476.

HEBERLE-BORS, E. 1982. In vitro pollen embryogenesis in Nicotiana tabacum L. and its relation to pollen sterility, sex balance, and floral induction of pollen donor plants. Planta 156:396-401.

HEBERLE-BORS, E. \& REINERT, J. 1979. Androgenesis in isolated pollen cultures of Nicotiana tabacum: dependence upon pollen development. Protoplasma 99:237-245.

HENRY, I. 1998. Origin of microspore-derived dihaploid and polyhaploid in vitro plants. Plant Tissue Culture and Biotechnology 4:127-135.

HORNER, M. \& STREET, H.E. 1978. Pollen dimorphism origin and a significance in pollen plant formation by anther culture. Annals of Botany 42:763-771.

ILIC'-GRUBOR, K., ATTREE, S.M. \& FOWKE, L.C. 1998. Comparative morphological study of zygotic and microspore-derived embryos of Brassica napus L. as revealed by scanning electron microscopy. Annals of Botany 82:157-165.

KALTCHUK-SANTOS, E., MARIATH, J.E., MUNDSTOCK, E., HU, C. \& ZANETTINI, M.H.B. 1997. Cytological analysis of early microspore divisions and embryo formation in cultured soybean anthers. Plant Cell Tissue and Organ Culture 49:107-115.

KALTCHUK-SANTOS, E., ZANETTINI, M.H. B. \& MUNDSTOCK, E. 1993. Pollen dimorphism in soybean. Protoplasma 174:74-78.

KNOX, R.B. 1984. The pollen grain. In Embryology of angiosperms (B.M. Johri, ed.). Springer Verlag, Berlin, p.197-271.

KRESS, W.J. \& STONE, D.E. 1982. Nature of the sporoderm in monocotyledons, with special reference to the pollen grains in Canna and Heliconia. Grana 21:129-148

LIU, D.P. \& ZHAO, G.L. 1986. Callus formation from pollen culture in vitro of soybean. Soybean Science 5:17-20.

MAHESHWARI, P. 1950. An introduction to the embryology of angiosperms. McGraw-Hill Publisching Company Ltd., New Delhi.

MAHESHWARI, S.C., RASHID, A. \& TYAGI, A.K. 1982. Haploid from pollen grains - retrospect and prospect. American Journal of Botany 69:865-879.

MAHESHWARI, S.C., TYAGI, A.K. \& MALHORTA, K. 1980. Induction of haploidy from pollen grains in angiosperms - the current status. Theoretial and Applied Genetic 58:193-206 
MCDOWELL, E.M. \& TRUMP, B. 1976. Histological fixatives for diagnostic light and electron microscopy. Archives of Pathology \& Laboratory Medicine 100:405-414.

O'BRIEN, T.P. \& MCCULLY, M.E. 1981. The study of plant structure. Principles and selected methods, Termarcarphi Pty Ltd., Melbourne.

OLIVEIRA, J.M.S. 1998. Desenvolvimento da antera e andrófito no clone CP76 de Anacardium occidentale (Anacardiaceae). Monografia de bacharelado, Universidade Federal do Rio Grande do Sul, Porto Alegre.

OLIVEIRA, J.M.S. \& MARIATH, J.E.A. 2001 Anther and pollen development in Anacardium occidentale (Anacardiaceae) clone CP76. Phytomorphology 51:91100.

RASHID, A. 1983. Pollen dimorphism in relation to pollen plant formation. Physiologia Plantarum 58:544-548.

REYNOLDS, T.L. 1993. A cytological analysis of microspores of Triticum aestivum (Poaceae) during normal ontogeny and induced embryogenic development. American Journal of Botany 80:569-576.

RUSSEL, S.D., STROUT, G.W., STRAMSKI, A.K., MISLAN, T.W., THOMPSON, R.A. \& SCHOEMANN, L.M. 1996. Microgametogenesis in Plumbago zeylanica (Plumbaginaceae). 1. Descriptive cytology and threedimensional organization. American Journal of Botany 83:1435-1453.

SANGWAN, R.S. 1986. Formation and cytochemistry of nuclear vacuoles during meiosis in Datura. European Journal of Cell Biology 40:210-218.

SANGWAN, R.S. \& SANGWAN-NORREEL, B.S. 1987. Biochemical cytology of pollen embryogenesis. International Review of Cytology 107:221-272.

SUNDERLAND, N. 1973. Pollen and anther culture. In Plant tissue and cell culture (H.E. Street, ed.), Oxford Blackwell. p.205-239.

SUNDERLAND, N. \& EVANS, L.J. 1980. Multicellular pollen formation in cultured barley anthers. Journal of Experimental Botany 31:501-514.

SUNDERLAND, N. \& HUANG, B. 1987. Ultrastructural aspects of pollen dimorphism. International Review of Cytology 107:175-220.
SUNDERLAND, N. \& WICKS, F.M. 1971. Embryoid formation in pollen grains of Nicotiana tabacum. Journal of Experimental Botany 22:213-226.

SUNDERLAND, N., COLLINS, G.B. \& DUNWELL, J.M. 1974. The role of nuclear fusion in pollen embryogenesis of Datura innoxia Mill. Planta 117:227-241.

TANAKA, I. 1997. Differentiation of generative and vegetative cells in angiosperm pollen. Sexual Plant Reproduction 10:1-7.

TANAKA, I. \& ITO, M. 1981. Control of division patterns in explanted microspores of Tulipa gesneriana. Protoplasma 108:329-340.

TANAKA, I., ONO, K. \& FUKUDA, T. 1998. The developmental fate of angiosperm pollen is associated with a preferencial decrease in the level of histone $\mathrm{H} 1$ in the vegetative nucleus. Planta 206:561-569.

TOURAEV, A., VICENT, O. \& HEBERLE-BORS, E. 1997. Initiation of microspore embryogenesis by stress. Trends in Plant Science 2:297-302.

UEDA, K., KINOSHITA, Y., XU, Z., IDE, N., ONO, M., AKAHORI, Y., TANAKA, I. \& INOUE, M. 2000. Unusual core histone specifically expressed in male gametic cells of Lilium longiflorum. Chromosoma 108:491-500.

WILSON, H.M., MIX, G. \& FOROUHGI-WEHR, B. 1978. Early microspore divisions and subsequent formation of microspore calluses at high frequency in anthers of Hordeum vulgare. Journal of Experimental Botany 29:227-238

YU, H. \& RUSSEL, S.D. 1994. Male reproductive cell development in Nicotiana tabacum: male germ unit associations and quantitative cytology during sperm maturation. Sexual Plant Reproduction 7:324-332.

ZAKI, M.A.M. \& DICKINSON, H.G. 1991. Microsporederived embryos in Brassica: the significance of division symmetry in pollen mitosis I to embryogenic development. Sexual Plant Reproduction 4:48-55. 